doi:10.5559/di.21.4.11

\section{IZAZOVI I MOGUĆNOSTI ZA OSTVARENJE PRIMJERENIH STAROSNIH MIROVINA U hRVATSKOJ}

Ekonomski institut, Zagreb, $2011 ., 112$ str.

\section{CROATIA: POLICY OPTIONS FOR FURTHER PENSION SYSTEM REFORM}

World Bank, Zagreb, $2011 ., 45$ str.

Mirovinski sustav u suvremenom društvu ima više funkcija, a glavne su ravnomjerna raspodjela dohotka pojedinaca i obitelji cijeloga životnog vijeka, poticanje pojedinačne i nacionalne štednje te ublažavanje siromaštva $u$ vrijeme starosti i radne neaktivnosti. Funkcije mirovinskoga sustava mogu se ostvarivati na razne načine, pa stoga postoje i razni modeli mirovinskoga sustava izrasli iz tradicija socijalne politike pojedine zemlje ili skupina zemalja. Zbog mnogih razloga mirovinski sustav u Hrvatskoj, kao i u mnogima drugim posebice posttranzicijskim zemljama Središnje i Istočne Europe, u velikim je poteškoćama. To su prije svega nepovoljan odnos između broja osiguranika i umirovljenika, velik broj umirovljenika koji pojedinačno primaju male mirovine s tendencijom njihova daljnjeg smanjivanja, visoka izdvajanja za mirovinsko osiguranje, rano se odlazi u mirovinu uz razmjerno kratak staž osiguranja, građani uglavnom ne štede za mirovinu i ve- lika su očekivanja od države. Konačno, često se donose brzoplete i nedovoljno promišljene odluke vezane uz promjene mirovinskoga sustava i prava, što je djelomično uzrokovano razmjerno rijetkim sustavnim istraživanjima o složenim obilježjima i problemima mirovinskog osiguranja.

Nedavno su svjetlo dana ugledale dvije hvalevrijedne studije koje bi mogle znatno poboljšati opća znanja stanovništva o mirovinskom sustavu. Prvo je istraživanje Izazovi i mogućnosti za ostvarenje primjerenih starosnih mirovina u Hrvatskoj, koje je pripremio Ekonomski institut iz Zagreba, a veću skupinu istraživača s Ekonomskog instituta i Pravnog fakulteta te stručnjaka iz Hrvatskoga zavoda za mirovinsko osiguranje vodio je urednik studije, Danijel Nestić. Sama studija pripremljena je s namjerom da se analiziraju stanje i problemi, pouzdane projekcije budućega kretanja mirovina te prijedlozi potrebnih mjera za poboljšanje primjerenosti mirovina $u$ Hrvatskoj. Studija se sastoji od dva glavna dijela. U Uvodu urednik upozorava kako je u mirovinskom osiguranju presudno osigurati primjerenost mirovina i dugotrajnu financijsku održivost sustava. Iako ne postoje jednoznačne i precizne definicije primjerenosti i održivosti, općenito je prihvaćeno kako primjerenost znači očuvanje životnoga standarda umirovljenika, dok se održivost određuje u smislu mogućnosti da takav sustav ima dugoročno osiguranu pokrivenost nastalih rashoda.

U prvom dijelu studije izlažu se problemi i opisuje reforma mirovinskoga sustava u Hrvatskoj, ponajviše proširenje obračunskog razdoblja u izračunu mirovine, uvođenje privatnoga mirovinskog osiguranja i kapitalizirane štednje, podizanje dobi za odlazak u mirovinu i izjednačavanje dobi umirovljenja za žene i muškarce te, konačno, veće kažnjavanje prijevremenog umirovljenja. Uz pogoršanje odnosa broja aktivnih osiguranika i umirovljenika, razmjerno kratko razdoblje plaćanja staža osiguranja i istodobno dugo uživanje mirovine zbog povećanja očekivanoga trajanja života ne treba čuditi kako su ukupni miro- 
vinski rashodi pokriveni prihodima od doprinosa tek nešto više od polovice (54 posto), dok se razlika nadoknađuje transferima iz proračuna od gotovo 5 posto BDP-a. Tako je mirovinski sustav postao jedan od glavnih uzročnika deficita središnje države. Prosječna starosna mirovina umanjena za porez i prirez potkraj 2010. godine iznosila je 43,7 posto prosječne neto plaće, pri čemu je prosječna prijevremena starosna mirovina bila nešto niža i iznosila 41,5 posto prosječne plaće, dok je redovita starosna mirovina iznosila 44,1 posto prosječne plaće. Tako je prosjek svih mirovina (starosne, invalidske i obiteljske mirovine) iznosio 39,7 posto prosječne neto plaće.

U dionici posvećenoj primjerenosti objašnjava se kako u mirovinskom osiguranju postoje tri pristupa tom pojmu: individualni omjer zamjene (odnosno udio mirovinskih primanja $\mathrm{u}$ prosjeku cjeloživotne zarade osobe), relativna bruto mirovina (udio mirovinskih primanja u prosječnoj plaći na razini cijelog gospodarstva) te $m i-$ rovinska imovina (što podrazumijeva diskontiranu vrijednost očekivanih budućih mirovina u odnosu na sadašnju prosječnu plaću). Pojedini teoretičari čak razlikuju primjerenost, odnosno jamstvo određenoga minimalnog životnog standarda za starije stanovništvo (kao relativnu visinu bruto mirovine), od osiguranja određenoga životnog standarda nakon umirovljenja $u$ odnosu na onaj ostvaren za vrijeme radnoga vijeka.

Prema nalazima ove studije, neto stopa zamjene (udio prosječne mirovine $\mathrm{u}$ prosječnoj plaći) za prosječnog radnika samo u prvom stupu trebala bi u Hrvatskoj pasti otprilike sa 55 posto u 2010. godini na ispod 40 posto u 2048. godini. Tako bi Hrvatska 2050. godine mogla imati najnižu početnu stopu zamjene $u$ EU-u, time što će $u$
Hrvatskoj mirovine iz mješovitoga sustava biti još niže. Pritom se u studiji naglašava kako dio mirovine koji se isplaćuje na temelju kapitalizirane štednje (drugi stup) nije ključan za objašnjenje razlike, jer drugi stup djeluje u skladu s razumnim očekivanjima i sasvim usporedivo sa sličnim sustavima u drugim zemljama jer ostvaruje razumno očekivane mirovine. Glavni razlog još nepovoljnijega položaja osiguranih i u drugom stupu jest posljedica dodatka na mirovinu od 27 posto, na koji zasad nemaju pravo korisnici mješovitih mirovina. Rizik siromaštva u mirovini najveći je za umirovljenike koji su imali kratak radni staž ili primali niske plaće, a pogotovo su siromaštvu izloženi oni koji su kratko raditi i za to vrijeme bili slabo plaćeni. Osobe starije od 65 godina sada u Hrvatskoj imaju iznadprosječan rizik od siromaštva, koji je 1,7 do 1,8 puta veći nego za ukupno stanovništvo. Jedna od važnih mogućnosti povećanja životnoga standarda umirovljenika i poboljšanja održivosti sustava jest produljenje radnoga vijeka. U cilju stvaranja jasnih poticaja za duži ostanak u svijetu rada i poboljšanja pravednosti sustava treba očuvati i ojačati korekcije faktora umanjenja (uvećanja) mirovina kod prijevremenoga (kasnijeg) umirovljenja.

U dijelu o projekciji prihoda i rashoda mirovinskoga sustava objašnjava se kako prema provedenim izračunima usprkos nepovoljnim demografskim trendovima proizlazi da bi u Hrvatskoj izdaci obveznih mirovinskih sustava trebali smanjivati svoj udio u BDP-u. Tako bi se ukupni izdaci za mirovine iz javnoga sustava međugeneracijske solidarnosti tekuće raspodjele i obveznoga privatnog kapitaliziranog sustava smanjili sa 10,6 posto BDP-a u 2010. na oko 8,0 posto BDP-a u 2050. godini, pri čemu je smanjivanje izdataka iz javnoga sustava još intenzivnije te bi oni sredinom stoljeća mogli pasti na 5 posto BDP-a. U Hrvatskoj do sredine tekućega stoljeća nepovoljan utjecaj na mirovinske izdatke javnoga sustava imat će starenje stanovništva, no ostali čimbenici (ponajviše smanjivanje relativne visine mirovina, ali i po- 
većanje stope zaposlenosti te usporavanje priljeva u mirovinu) omogućit će njihovo ukupno smanjivanje.

Na temelju ovih spoznaja, iznose se prijedlozi pri čemu se naglašava kako se ne smije dalje smanjivati prosječna stopa neto zamjene za starosnu mirovinu iz javnoga i obveznoga privatnog mirovinskog sustava. Najvažnija je poruka kako nema potrebe za radikalnim zaokretom $\mathrm{u}$ smjeru reformi, poput ukidanja drugoga stupa. U ostvarivanju mogućih promjena treba izbjegavati žurna ili nedovoljno promišljena rješenja, koja samo mogu pogoršati održivost i pravednost sustava.

U drugom dijelu publikacije Ekonomskog instituta sadržane su odabrane teme vezane uz mirovinsko osiguranje, kao što su rizik prinosa u obveznom kapitalno financiranom mirovinskom podsustavu. Tu se pobliže razlažu hrvatskim čitateljima prilično slabo poznati fenomeni poput rizika prinosa u fazi akumulacije $i$ mjere zaštite od negativnoga i nedostatnoga prinosa. Na temelju iznesenih pozitivnih i negativnih obilježja raznih regulativnih modela navodi se kako bi u Hrvatskoj ubuduće trebalo razmotriti mogućnosti povećanja zajamčenoga prinosa manjim umanjenjem referentnoga prinosa $\mathrm{i}$ vezanjem prinosa uz stopu apsolutnoga prinosa. Kod razmatranja rizika prinosa u fazi isplate za Hrvatsku predlaže se očuvanje kupovne vrijednosti ugovorene mirovine uz pomoć pravila za usklađivanje mirovine sa stopom potrošačkih cijena; razvoj pravila za ulaganje i održavanje sredstava tehničke pričuve te stvaranje drugih oblika pričuva i osnivanje računa mirovinskoga jamstva kada mirovinska osiguravajuća društva koja isplaćuju mirovinu iz obveznoga sustava ne mogu redovito isplaćivati sukladno ugovoru o mirovini.
Ujedno se na temelju međunarodnih iskustava izlaže stanje $i$ važnost mirovinske pismenosti. Financijsko opismenjavanje ili financijsko obrazovanje razmjerno je nova aktivnost započeta prije desetak godina $\mathrm{u}$ razvijenim zemljama, koja dobiva na značenju u uvjetima sve starijega stanovništva te sve složenijih i raznovrsnijih oblika mirovinskog osiguranja. Često se naglašava kako zbog razmjerno kratkoga radnog vijeka i nepostojanja veće privatne štednje vlada opravdana bojazan da će izloženost siromaštvu budućih naraštaja starijih osoba biti viša nego kod ostaloga stanovništva. Kako bi imali pristojan standard u starosti, građani na vrijeme moraju početi štedjeti i ne očekivati preveliku pomoć od države. Zato moraju poboljšati svoju svijest i sposobnost ocjenjivanja primjerenosti financija u javnim i privatnim izvorima mirovinskog osiguranja. Stoga je u cilju boljega poznavanja djelovanja financijskih tržišta nužno promovirati financijsku i mirovinsku pismenost, pri čemu se znatna pomoć može dobiti od međunarodnih institucija, kao što su OECD-e, Svjetska banka i Europska komisija.

U zadnjem dijelu publikacije iznosi se deset hvalevrijednih prijedloga (koji se pobliže objašnjavaju), među kojima je potreba uravnoteženja mirovina iz mješovitoga sustava s mirovinama koje se isplaćuju samo iz prvoga stupa, i to prije svega proširenjem dodatka na sve korisnike mirovina, ovisno o vremenu koje su proveli u prvom stupu. Nadalje, upozorava se na potrebu osnaživanja veze između plaćenih mirovinskih doprinosa i visine mirovine. Treba razviti i usvojiti pravila za automatsku korekciju parametara javnoga mirovinskog sustava s očekivanim trajanjem života i gospodarskim kriterijima. Važno je razmotriti socijalno prihvatljiv i fiskalno održiv sustav valorizacije i indeksacije mirovina. Nužno je uvesti temeljni mirovinski stup (nulti stup) na načelu provjere resursa koji bi osigurao nužna primanja za starije osobe koje ne ostvaruju mirovinska prava. U drugom stupu treba razvijati i una- 
prijediti mehanizme kontrole rizika prinosa. Kao trajni zadatak svih dionika valja povećati transparentnost mirovinskoga sustava, odnosno ostvariti jednostavniji pristup informacijama o uplaćenim doprinosima, o očekivanoj visini mirovine i izračunu mirovine iz drugoga stupa. Kao sastavni dio jačanja stručnih i administrativnih kapaciteta najvažnijih dionika mirovinskoga sustava, treba reformske aktivnosti temeljiti na rezultatima znanstvenih i stručnih istraživanja. U okviru svih mjera i politika treba poticati rad i zapošljavanje. Konačno, nužno je ojačati svijest o individualnoj odgovornosti građana za primanja u starosti te ih upoznati s prednostima i rizicima raznih oblika osiguranja primanja u starosti. Studija je dostupna na mrežnoj stranici http://www.eizg.hr.

Drugu publikaciju pod nazivom Croatia: Policy Options for Further Pension System Reform pripremili su stručnjaci Svjetske banke. Riječ je o analizi koja prati ažuriranje modela za ocjenu fiskalnih učinaka u mirovinskom sustavu (PROST) koji bi trebao dati preciznije dugoročne projekcije fiskalnoga stanja mirovinskoga sustava. U travnju 2010. Vlada RH prihvatila je Program gospodarskog oporavka $i$ razvitka, namijenjen očuvanju makroekonomske stabilnosti i podršci za brži razvoj privatnoga sustava. Važan sastavni dio Programa jest analiza i prijedlog potrebnih mjera za očuvanje dugotrajne fiskalne održivosti mirovinskoga sustava, s posebnim naglaskom na očuvanju pristojnih mirovina u uvjetima starenja stanovništva. Iako su napravljene mjere ušteda (veće kažnjavanje prijevremenog umirovljenja, smanjivanje povlaštenih mirovina, mirovine iz I. stupa nisu usklađivane u 2010. godini, pa im se vrijednost realno smanjila približno za 1\%) koje su omogućile kratkotrajno ubla- žavanje fiskalnih pritisaka, to nije bilo dovoljno za osiguranje dugotrajne financijske održivosti.

Stoga je Vlada preko nadležnoga tijela - a to je Ministarstvo gospodarstva, rada i poduzetništva - zamolila Svjetsku banku za podršku u oblikovanju reforme i za razvoj simulacijskoga model koji bi olakšao donošenje potrebnih odluka. U ovoj publikaciji izneseni su najvažniji savjeti provedene analize, kojoj je cilj pomoći u raspravama oko poboljšanja cjelokupnoga mirovinskog sustava.

Hrvatsku obilježava pogoršanje demografskih pokazatelja, niska stopa aktivnosti, niske i opadajuće stope zamjene, neodgovarajuće mirovine iz miješanog oblika osiguranja (prvi i drugi stup), velike razlike $u$ iznosima mirovine za naraštaje koji su u različita vremena odlazili u mirovinu te prebrojne i preizdašne povlaštene mirovine. Najvažniji zaključak iz ove publikacije jest kako u hrvatskom mirovinskom sustavu svakako treba otkloniti razlike između visina mirovina u prvom stupu i miješanom sustavu. Razlika je nastala zbog dodatka od $27 \%$, na koji imaju pravo samo umirovljenici I. stupa. Tako bi pravo na navedeni dodatak trebalo proširiti i na osiguranike drugoga stupa u skladu s brojem godina koje su proveli u prvom stupu i plaćenih doprinosa za prvi stup. U publikaciji se navodi kako moguće otvaranje drugoga stupa za izlaz narušava sustav, a pogotovo dovodi u nepovoljan položaj one koji nisu mogli birati žele li se uključiti u drugi stup. Potrebna je i promjena osnovnih mirovinskih parametara $u$ udjelu doprinosa koji se izdvajaju za sustav međugeneracijske solidarnosti. Mogućom kombinacijom ovih mjera povećat će se stopa zamjene, odnosno podiže se iznos mirovina u odnosu na plaće. Ipak, na dulji rok tako se stvara potreba za izdvajanje dodatnih 1,2 posto BDP-a godišnje do 2035. godine, odnosno 3,2 posto do 2060 . godine, što podrazumijeva do 2060. povećanje mirovinskoga duga za 80 posto BDP-a u odnosu na zadržavanje postojećega stanja. 
Druga mogućnost jest uvođenje cenzusa prihoda i/ili imovine kao uvjeta za ostvarivanje prava na spomenuti dodatak.

Nastavak indeksacije uz upotrebu sadašnje švicarske formule povećao bi do 2020. godine deficit svake godine za približno 0,8 posto BDP-a u usporedbi s potpunom valorizacijom $\mathrm{s}$ porastom plaća $\mathrm{i}$ indeksacijom $u$ odnosu na cijene, što su prema međunarodnim iskustvima najbolja rješenja. Povećanje stope doprinosa za drugi stup na 10 posto u sljedećih pet godina stabiliziralo bi i povećalo mirovine koje se isplaćuju iz mješovitoga sustava u odnosu na plaće, ali bi značilo značajan financijski napor, odnosno dodatne visoke transfere od gotovo 2 posto BDP-a. Ipak, ako bi osnovna mirovina bila usklađena s umanjenim izdvajanjima za prvi stup, neto troškovi povećanja doprinosa za drugi stup mogli bi se smanjiti na polovicu.

Sve navedene mjere značajno bi povećale troškove mirovinskoga sustava ako ih istodobno ne bi pratile možebitne uštede. S obzirom na visok deficit proračuna središnje države i nagli porast javnoga duga, u srednjoročnom razdoblju nastoji se postići proračunska uravnoteženost. Kako bi se to ostvarilo, nužno je djelovanje na više područja. Treba ograničiti daljnje povećanje broja korisnika mirovina ostvarenih pod posebnim (povoljnijim) uvjetima i usporiti rast visine tih mirovina kako bi se postigla njihova konvergencija prema mirovinama običnih umirovljenika. Kako smo već naveli, treba prijeći na valorizaciju u skladu s porastom plaća $\mathrm{i}$ indeksaciju u odnosu na cijene. Dosljednim kažnjavanjem ranijeg umirovljenja nužno je ograničiti prijevremeno umirovljenje. Ujedno, do 2030. treba podići zakonsku dob umirovljenja na 67 godina, što bi povisilo relativne mirovine i smanjilo fi- skalni deficit sustava. Važno je smanjivanje administrativnih troškova i snižavanja ulaznih i upravljačkih naknada te podjela troškova prikupljanja doprinosa s društvima koja upravljaju obveznim mirovinskim fondovima. Konačno, valja smanjiti fiskalni utjecaj mirovinskoga dodatka iz 2007. godine, čime bi se mogle postići osjetne financijske uštede, ali bi istodobno moglo značiti i povećanje umirovljenika koji su izloženi siromaštvu.

Posve je očito kako u navedenim uvjetima povećanje stope doprinosa za drugi stup predstavlja poteškoću, ali ipak ta bi se mjera mogla opravdati većim budućim stopama zamjene i manjim implicitnim mirovinskim dugom u odnosu na postojeće stanje. Odgađanje povećanja stope doprinosa za drugi stup negativno bi utjecalo na mirovine iz miješanog osiguranja, a i budućim bi naraštajima stvorilo osjetan financijski teret. Naravno, postoji mogućnost povećanja ukupnih doprinosa za mirovinsko osiguranje, ali bi se time povisili ionako visoki troškovi rada, narušila konkurentska sposobnost hrvatskoga gospodarstva te konačno potaknulo sudjelovanje $u$ neslužbenom gospodarstvu (sivoj ekonomiji). Tako bi, po mišljenju stručnjaka Svjetske banke, to trebala biti zadnja mjera. Oni naglašavaju kako se moguće povećanje stope doprinosa za drugi stup može ostvariti samo u uvjetima fiskalnih mogućnosti koje dopuštaju takvo djelovanje. Ova studija dostupna je na mrežnoj stranici http://siteresources.worldbank. org/INTCROATIA/Resources/Croatia_Poli cy_Notes-Pension.pdf.

Mirovinska reforma i promjene $u$ mirovinskom osiguranju složene su, jer su gubici očiti, neposredni i većinom točno usmjereni prema pojedinim društvenim skupinama. Koristi su nevidljive, dugoročne, raspršene i, naravno, izazivaju protivljenje osiguranika. Ipak, promjene su nužne ako se želi očuvati mirovinski sustav u promijenjenim uvjetima života i rada. Treba postići dugoročno uravnotežen i održiv mirovinski sustav, odnosno prekinuti potrebu za pretjeranim transferima iz 
državnoga proračuna, čime bi se trebala smanjiti izloženost mirovinskoga sustava političkim intervencijama. U svemu navedenom ove dvije studije svojim vrlo stručnim razmatranjem, razumljivošću i jasnim prijedlozima mogu biti vrlo korisne donositeljima odluka, ali i građanima da dobiju uvid u mirovinski sustav.

Predrag Bejaković

\section{doi: $10.5559 /$ di.21.4.12 \\ Ivan Burić NACIJA ZADUŽENIH Od komunističkog pakla do potrošačkog kapitalizma}

Naklada Jesenski i Turk, Hrvatsko sociološko društvo, Zagreb, 2010., 333 str.

Knjiga sociologa Ivana Burića "Nacija zaduženih: Od komunističkog pakla do potrošačkog kapitalizma", objavljena 2010. godine u izdanju Naklade Jesenski i Turk, sastoji se od 10 poglavlja, zaključnih razmatranja te prikaza dijela istraživanja vrijednosnih orijentacija koje je 2009. godine provela agencija Puls.

Da bi odgovorili na pitanje zašto su se na početku 21. stoljeća hrvatski građani intenzivno zaduživali, kao i na pitanje je li to zaduživanje bilo prekomjerno i neracionalno, Burić analizira načine na koje je "konstitucija potrošačkog društva u Hrvatskoj utjecala na rast osobne zaduženosti" (Burić, 2010., 68), suprotstavljajući se često pojednostavnjenim analizama ovoga novog društvenog fenomena. U uvodnom poglavlju (Pucnjava na parkingu trgovačkog centra $i$ susjedski obračun na Jankomiru) autor tako objašnjava kako je problem prekomjernoga trošenja i zaduženosti u zbilju hrvatskoga društvenog života uvela tranzicija, koju Županov tumači kao društveni proces svojstven za Hrvatsku u prvoj polovici devedesetih godina 20 . stoljeća, temeljna obilježja kojih jesu privatizacija i marketizacija. Simbolički završetak tranzicije našega društva iz samoupravno-socijalističkoga u tržišno i potrošačko Burić nalazi u pucnjavi zbog parkirnoga mjesta ispred trgovačkoga centra u Zagrebu 2006. godine, navodeći kako smo u petnaestak godina prešli put iz "života pucnjave na frontu" $u$ "život pucnjave na parkiralištu".

Odbacujući uz pomoć statističkih podataka kao trivijalne koncepte kojima se u medijima najčešće objašnjava rast osobne zaduženosti u Hrvatskoj - koncept urođenoga konzumerizma koji zaduženost tumači kao posljedicu urođenoga kolektivnog mentaliteta i sklonosti Hrvata neracionalnom trošenju te koncept ekonomskoga propadanja koji život na dug promatra kao alat za preživljavanje zbog porasta siromaštva - autor u drugom poglavlju (Teorijski koncept) objašnjava kako svoju anali$\mathrm{zu}$ intenziviranja potrošnje i rasta osobne zaduženosti temelji na Giddensovoj ideji strukturacije i konceptu socijalne strukture. Slijedom toga pristupa predmet analize fenomena osobne potrošnje iz diskursa karakterističnoga za psihologiju potrošnje ili za ekonomiju vraća u diskurs karakterističan za sociologiju, a rast osobne zaduženosti u Hrvatskoj sagledava kao posljedicu interakcije ciljno usmjerenih aktera i konfiguracije novouspostavljenih struktura potrošačkoga društva.

U trećem poglavlju (Potrošačko društvo i društvena struktura), nakon skiciranja pojma društvene strukture u sociološkoj misli, autor pruža prikaz razvoja društvene strukture potrošačkoga društva, koje se može promatrati kao specifičan oblik društvene konstitucije kasne modernosti $u$ kojemu su razvijene i posebno istaknute one strukturalne komponente koje su usmjerene prema poticanju i intenziviranju 